\title{
Research on the Human Resource Management Practices
}

\author{
Zheng Jin
}

\author{
Address: Chongqing College of Electronic Engineering, Chongqing, China \\ Email:460470325@qq.com
}

Keywords: Human Resource Management, Practices, Research

\begin{abstract}
Globalization, digitization and networking features into a new economic era, human resources management is directly related to the success or failure of its operation on health and long-term development has become increasingly prominent and critical role. The traditional personnel management was no longer meet the needs of enterprise development, human resource management, is moving into the era of strategic human resource management, it has been elevated to a strategic level up treatment. Enterprises should make the practice of strategic human resource management, in order to form their own core competencies, in order to achieve sustainable competitive advantage in the fierce market competition.
\end{abstract}

\section{Introduction}

With China's accession to WTO and the liberalization of regulated industries, enterprises are facing increasingly fierce competition in the global scale. Enterprises to achieve sustained growth and development, it is necessary in the capital resources, market conditions and other constraints, continue to tap the resources and creating a competitive advantage to win the initiative in the market competition. In case of such resource constraints, the functions of the enterprise must be able to create value for human resources activities and human resources for the rationality of human resource management activities as well as the use of resources also need to be evaluated.

Modern human resources management system emphasizes on through proper incentive and restraint mechanisms, through the staff selection, use, education, stay for effective management, and create a very relaxed atmosphere and a broad development space for employees, in order to fully motivate employees for the enterprise goals. However, in our country many business to business investment and human resource management activities cannot correctly understand the value will still be regarded as HR organizational structure accessories, belonging to the auxiliary and support, will only produce excess activities and procedures; investment in human resources is also considered a simple labor costs, but will not create any value. In this context, the HR function to be proven in human resource investment and management in the enterprise value-added chain is not superfluous, especially to illustrate through human resource management activities that can improve business performance and competitiveness. Therefore, human resource activities on business performance in the end whether the contribution, how much contribution to this effect or contribution is how to achieve, human resource management activities played what role in this process contributed, had been the theory practitioners and issues of common concern.

\section{Development and Transformation of Human Resource Management Practices}

The overall change in the field of human resources management in the recent research and practice has been further strengthened and show that these developments also showed a trend of integration practices and organizational management theory of human resource management. Mahoney further integrate these changes and trends summarized in the following five areas:

Transition from Human Resources Plan to Strategy. Previously HR plan refers to the enterprise human resources supply and demand forecast, in order to take recruitment, promotion, dismissal and other ways to achieve a balance, but the lack of effective guidance and evaluation (MiIkoviCh and Mahoney, 1979) on the effect of these actions. Unless considered on a deeper, more 
strategic level, the problems would not be solved. Since then, scholars and practitioners will focus on human resource planning is no longer just concerned about the short-term prediction analysis, but stressed the consistency of planning and organizational strategy. Research and practice after such changes have been achieved fully.

Transition from Labor Relations Management to Labor Governance. Labor relations and collective bargaining has been the practice of personnel work in an important work, the idea is to employees as an individual (a separate ground for recruitment, training and remuneration of the object), and use these models to analyze individual behavior topics. The workforce management is a relatively wider range of concepts, is a blend of traditional ideological field after field of labor relations and organizations produce, which enables employees outside the collective bargaining have more opportunities to participate in corporate management decisions. Thus, business managers and leaders know the way out of collective bargaining for more cooperation, so that the focus on employee relations from the relations between the two interest groups to coordinate the process model into a labor force participation and influence process model business decisions.

Transition from Employee Morale to Organizational Culture and Organizational Climate. In the study of early relationships, the morale is as a representative of the labor force characteristics, can potentially affect the performance of the terms of produce, which is as a characteristic of employee job satisfaction appears, its meaning is limited to the individual employee level. As an alternative organizational climate as to define a collective level appears, it is simply defined as work and organizational environment on employee beliefs, attitudes and motivation, generally it refers to the collective psychological environment and an organization of work and members of the status, organizational climate including individual employee attitudes and their impact on employee attitudes and behavior. The latest in the organizational culture of the organization is a reflection of the ideas, beliefs, and representations include staff wearing, behavior and organizational members of the anecdotes and the like.

Transition from Individual Work to Teamwork. Since the scientific management period, the staff has been on the individual as a basis for personnel management, job analysis and drafting of the job description is to be the key to recruitment, evaluation, compensation and staffing decisions and the like. The emergence of organizational behavior to motivate staff job enlargement and enrichment methods, the concept of making a job or work become less fixed and clear specifications, or to work as a job is no longer fixed organization detailed description of the task, but as a large part of a variable by job skills and responsibilities defined, members of the organization to be more teamwork.

Transition from Training to Development. Personnel management training is concerned that learning skills and specific conductivity type of behavior, the purpose is to control and reduce staff engaged in specific work behavior difference. The management of human resources development is concerned basic capability and enhances the quality of employees, members of the organization to achieve diversity by allowing employees to fully develop their potential. Training remains an important part of human resource management, but it increasingly includes consideration of the staff capacity development, such as employee career management, stress management, consulting and other employees included in the training, so as a part of the overall staff development plan. Overall, the transition from training to development is provided to employees from specific, work-oriented skills into the development of the full potential of employees. With the development of human resource management theory and research stage, the content of substantive work has become increasingly standardized, human resource management system into a truly comprehensive theory and science.

\section{The Characteristics of Human Resource Management Activities}

Human resources management is the impact of employee behavior, attitude and performance of a variety of policies, practices, and management system. Human resource management is an important organization will be a resource for employees to achieve organizational goals, and thus its effective management and use of ideas and practices, influence the behavior of employees, as well 
as a variety of policies and systems performance management practices and attitudes, through proper management staff selection, use, education, stay reunification individuals, enterprises and social benefits.

Modern human resources management systems typically include human resource planning, recruitment, selection, dismissal, training, performance appraisal, career development, compensation, labor relations management nine work content. Human resource management and personnel management compared with the following characteristics:

In terms of content, human resources management contains the contents of personnel management activities, but broader, more flexible mode of operation, content richer, more complex and gradually become linear functions of the enterprise. Relatively speaking, the content of Personnel Management on relatively simple, and is regarded as subsidiary of corporate functions.

For the purposes of the organization's strategy, it is a two-way relationship. That business strategy determines the direction and activities of human resource management and human resource management activities of planning and strategy to provide information and to verify the results. That is, the human resource management function has a broad, long-term future, strategic, holistic and future perspective of management, and personnel management functions are localized in some daily, short-term administrative affairs work.

For the purposes of work, human resources management activities focus on the needs of employees through their development and achieve organizational performance, long-term performance and ensure long-term development of the organization, to achieve a win-win for employees and organizations; and personnel management to focus on relatively short-term and individual performance, the purpose is to maximize short-term goals to achieve in order to protect the organization to achieve corporate earnings.

On the role of the operator in terms of human resource management sector to become the company's production and benefits department, human resource managers enterprise management decisions participant, control and planners; and personnel management stage, the personnel department is enterprises of non-production, non-sector efficiency, logistics services, personnel worker itself is executed by the operator.

\section{Functions of Modern Human Resource Management Practices}

(1) To help organizations achieve their goals in any target tissue requires the involvement of the HR initiative with the various needs of the organization, to help organizations achieve their goals.

Staffing

(2) Recruiting organization to supplement enterprise "fresh blood" organization to open up new production lines to increase the size of the business, mergers and other companies have put forward a lot of demand for human resources, human resources must help organizations obtain needed each class of suitable human resources. In addition, even without a business expansion, corporate officers will have "wear and tear", such as retirement, resignation, dismissal, resignation, death, natural wear and tear that inevitably need to add staff.

(3) Training of staff skills and competencies to meet organizational requirements management training grassroots and middle management personnel to enable them to exercise their management functions; general training of all employees on the job skills so that they can fit the needs of the post. So that the power of all employees converted into productive forces, for shareholders, customers and employees himself.

(4) Training morale and spirit of collaboration of staff to help organize building good team to properly motivate employees, enabling them to maintain a high morale and upward: to train employees team spirit, learn to accept and understand partners ; to train their persistent organizational goals and trust the leadership to help build a leadership team have a good strong combat effectiveness.

(5) Guidance staff career planning staff to provide maximum room for development career planning, career development and career management is proactive HR planning must work to help employees identify their work to find the right orientation and direction of development, test their 
aptitudes, professional competence and professional interests, develop their career planning and provide maximum space for development.

(6) Improve the quality of life of employees to achieve the quality of work life of employees high satisfaction include leadership management style, management style, employee participation in decision-making and management, security and stable career development, reasonable and satisfying work remuneration and satisfactory working conditions, good corporate image, improve the working environment of these enables employees to achieve high satisfaction.

(7) Strengthen the entire staff of human resource management policies to make communication in the company everyone understands human resource management purposes, methods and measures, this communication can not only exist, but should be continuous efforts their work is not only non-consumers, policy makers, other external public to communicate with consumers, but also to communicate with the full range of internal employees, workers must understand what they are for the organization's overall strategic objectives contribute.

(8) Social Responsibility Human Resources management and maintenance company policies and ethical behavior must praise the noble ethics and compliance with company policy behavior of employees, must ensure that any activities of human resource management is fair, impartial, comply with national laws, it is worth trust and withstand the supervision and inspection. To ensure that employees of human dignity will not be violated, their fundamental rights are protected, while maintaining business and employee behavior in line with ethical standards community, society, and encourage employees to become law-abiding model.

\section{Conclusion:}

Human Resources Management Performance between business performance and positive relationship, it has a positive impact on the role of human resource management on firm performance and employee satisfaction, organizational commitment, organizational citizenship behavior and customer satisfaction and other intermediate variables influence human resource practices enterprise performance plays a huge role as a bridge. In the increasingly fierce competition in the market, human resource management is to achieve its fundamental strategy, which affects the production efficiency and core competitiveness, customer satisfaction, market share, profits, and attractive and other resources aspect. To make any business to maximize their competitive ability, we must be able to successfully manage their human resources. How to establish a sound strategic human resource management system, establish a "high performance work system enterprise" to provide a staff satisfaction, organizational commitment, organizational citizenship behavior and customer satisfaction and other intermediate variables in human resource practices affect firm performance play in the role of a bridge good support and protection platform.

\section{References}

[1] Zhao Shuming: Singapore Human Resource, Vol. 6 (2014) No 53, p.25-26

[2] Hongli Zhang: World Economics and Politics, Vol. 12 (2015) No 27, p.74-76

[3] Qin Guo: Foreign Economy and Management, Vol. 1 (2010) No 33, p.11-14

[4] Jieming Liu: Financial and Economic Issues, Vol. 3 (2012) No33, p.121-124

[5] Qin Guo: Foreign Economics and Management, Vol. 1 (2010) No 33, p.114-117 